\title{
The Control of Weeds in Pineapple Fields with $\mathrm{CMU}^{1}$
}

\author{
H. R. Cibes ${ }^{2}$
}

\section{INTRODUCTION}

In a study conducted in 1948 by Piñero and Bayrón (2) ${ }^{3}$ it was found that the production costs of pineapple in Puerto Rico amounted to $\$ 456.84$ per acre, of which 59 percent was devoted to the cultivation of pineapple fields. Hand-labor was responsible for the major part of the cultivation expenses. This is used mainly for weeding the plantations. It is a wellknown fact that pineapple plants are spaced very closely in beds of two to three rows each. These beds are alternated by wide alleyways. Whereas mechanical devices can be used to cultivate the alleyways between the pineapple beds, all the weeding inside the beds must be done with hand hoes. The fact that pineapple plants are seriously affected by weed competition, and that weeds grow profusely because of favorable weather conditions in the pineapple region, it is necessary to perform many weedings during the year. This produces the previously mentioned prohibitive cultivation costs.

The most effective way of holding the weeding expense to a minimum is by the constant and systematic use of a weedicide that will control weeds both in the alleyways and between plants in the beds without injuring them. Craft and Emmanueli (1), seeking such a weedicide, tested eight commercial oil fractions in the field and the greenhouse. In the greenhouse only the light fraction, stove naphtha, proved to be safe for the plants. However, in the field tests all of them injured the plants. A dinitro compound, also tested by these investigators, damaged the plants without controlling the weeds.

Since these workers performed their experiments a considerable number of new herbicides have been developed. This paper reports the results obtained with CMU in the control of weeds in pineapples.

\section{PROCEDURE}

During the last part of the rainy season of 1954 two experiments were conducted on the use of CMU for controlling noxious weeds in pineapple

${ }^{1}$ Since this work was done the trade name of CMU, 3-(p-chlorophenyl)-1,1-dimethyl urea, was changed to Karmex $W$.

2 Associate Plant Physiologist, Agricultural lixperiment Station, University of Puerto Rico, Río Piedras, l'. R.

${ }^{3}$ Italic numbers in parentheses refer to literature Cited, p. 19. 
plantings. One began in October, the other in November. They were established in two different pineapple fields of the Smooth Cayenne variety growing in a Bayamón silty clay soil at Palo Alto in the vicinity of Manatí. The first experiment consisted of the application of CMU at various concentrations to pineapple plots about a month after planting. In the second the application of CMU was made at the same concentrations 6 months after planting. Three months later a second application of CMU was made to plots in the second experiment at the previous concentrations.

The CMU was applied with a knapsack sprayer in a pre-emergence spray at rates of $0,2,4$, and 6 pounds per acre in 100 gallons of water over all plots. This included both the pineapple beds and the alleyways. No special precautions were taken to prevent the spray solution from coming in contact with the pineapple plants.

The plots used in the first experiment consisted of two pineapple beds of three 12-foot rows each. There was a distance of about 18 inches between plants and between rows. An alleyway 4 feet wide separated the two beds in the plots. The plot size in the other experiment was the same except that the plot length was increased to 24 feet.

The weight of the weeds harvested from each experimental plot was used as the criterion for evaluating the effect of the various treatments. Weedings were made 3 months after the differential treatments were applied. No weed counts were made, but the various species growing in the plots were identified. Periodical inspections of the plants were made to determine whether any of the chemical treatments was injuring their appearance and/or growth. The various treatments in both experiments were arranged in the field according to the pair-plot design.

The first experiment was terminated about 3 months after the differential treatments were applied to the experimental plots, that is, right after the first weeding was performed. However, it was intended to carry the second one until the crop was harvested. This would have provided an opportunity to study not only the residual effect of the various CMU treatments, but also the effect, if any, of these treatments on the production and perhaps the quality of fruits. Unfortunately, this could not be accomplished because the cooperator ruined the experiment by cultivation after the first results were obtained.

\section{RESULTS}

Tables 1 and 2 present the mean weights of weeds harvested from pineapple plots in the above-described experiments.

The statistical analyses of these data clearly showed that the growth of weeds was significantly less in the CMU-treated plots at the 5- and 1-percent levels, than in the control plots in both experiments. In fact, the plots 
that received the CMU applications, especially those treated with the medium and high concentrations, were practically devoid of weeds, while

TABLE 1.-Mean weights of weeds harvested from pineapple plots treated with $C M U$ at different concentrations a month after planting

\begin{tabular}{c|c|c}
\hline Symbol & Treatments & Mean weight of weeds \\
\hline & & Pounds \\
A & 2 lb. CMU per acre & 2.51 \\
B & 4 lb. CMU per acre & .56 \\
C & 6 lb. CMU per acre & 0 \\
D & No treatment & 11.56 \\
\hline
\end{tabular}

Least significant difference between means of weight of weeds at:
5 -percent level
4.30

1-percent level

6.18

TABLE 2.-Mean weights of weeds harvested from pineapple plots treated with $C M U$ at different concentrations 6 and 9 months after planting

\begin{tabular}{c|c|c|c}
\hline & Treatments & \multicolumn{2}{|c}{$\begin{array}{c}\text { Mean weight of weeds harvested from } \\
\text { plots treated- }\end{array}$} \\
\cline { 2 - 4 } & & $\begin{array}{c}6 \text { months after } \\
\text { planting }\end{array}$ & $\begin{array}{c}9 \text { months after } \\
\text { planting }\end{array}$ \\
\hline & & Pounds & Pounds \\
A & 2 lb. CMU per acre & 2.54 & 1.25 \\
B & 4 lb. CMU per acre & 1.04 & 0 \\
C & 6 lb. CMU per acre & 0 & .25 \\
D & No treatment & 10.27 & 12.54 \\
\hline
\end{tabular}

Least significant difference between means of weight of weeds from plots treated 6 months after planting:
5 -percent level
2.12
1-percent level
3.04

Least significunt difference between means of weight of weeds from plots treated 9 months after planting:
5 -percent level
5.78
1-percent level
8.00

the checks exhibited a heavy stand 3 months after the experiments began (figs. 1 and 2).

The statistical analyses showed, moreover, that there were no significant differences between the weights of weeds harvested from plots treated with the different concentrations of CMU used in both experiments. From a practical point of view this means that, at least for a period of 3 months 

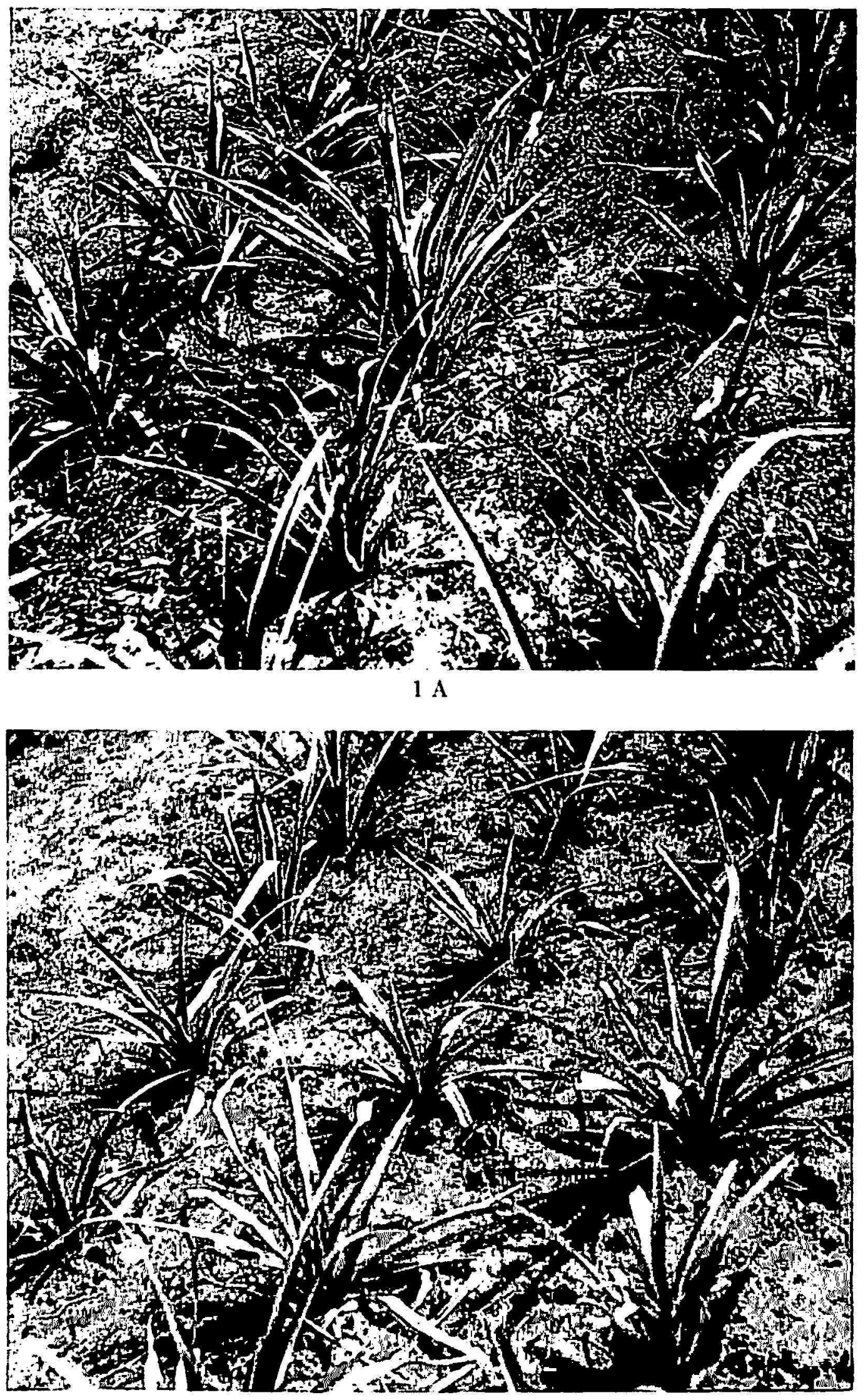

$1 \mathrm{~B}$

Fis. 1.-Control of weeds by CMU applied to pineapple plots a month after planting at rates of: $A, 2$ pounds per acre; $B, 4$ pounds per acre; $C, 6$ pounds per acre; $D$, control. 

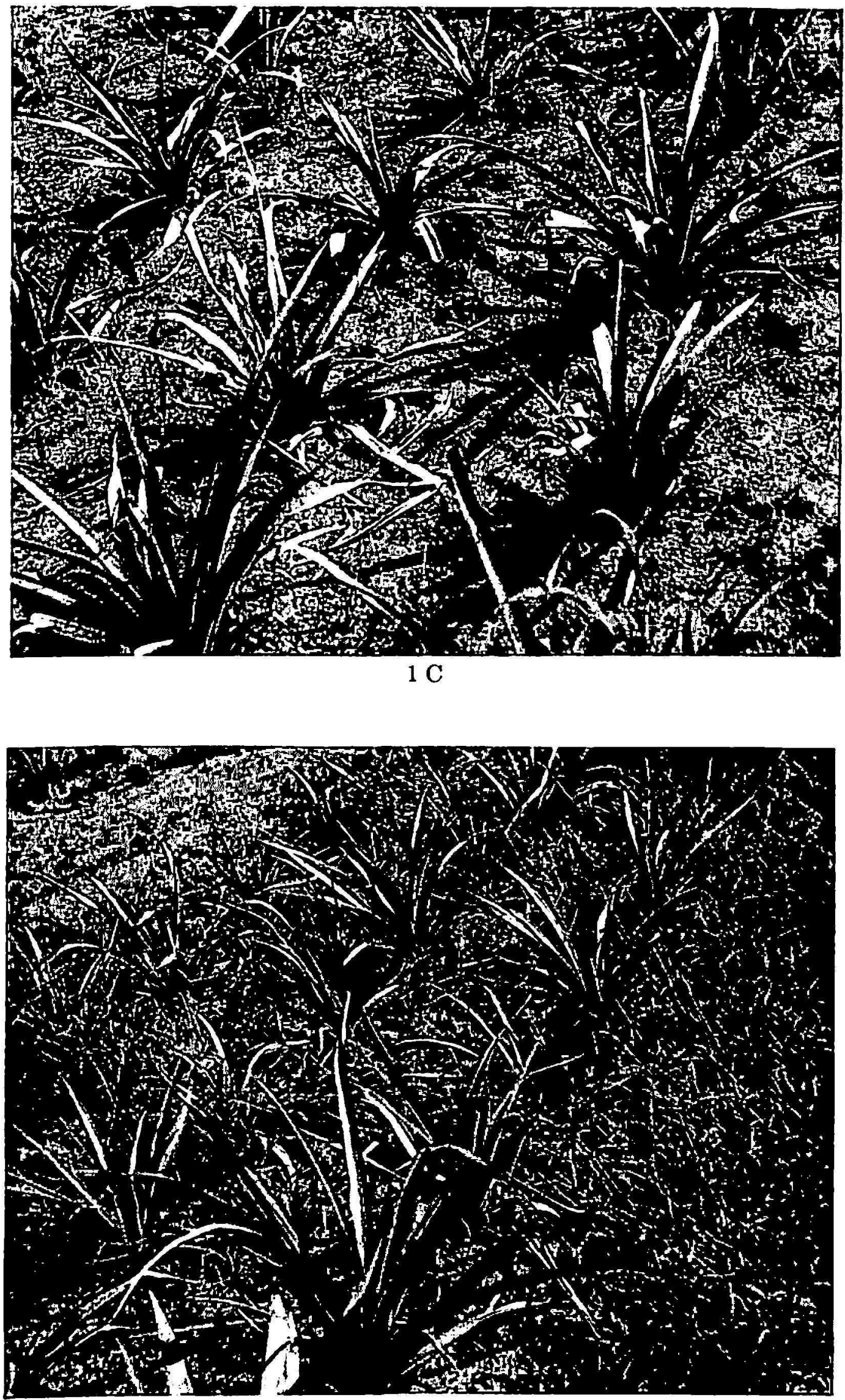


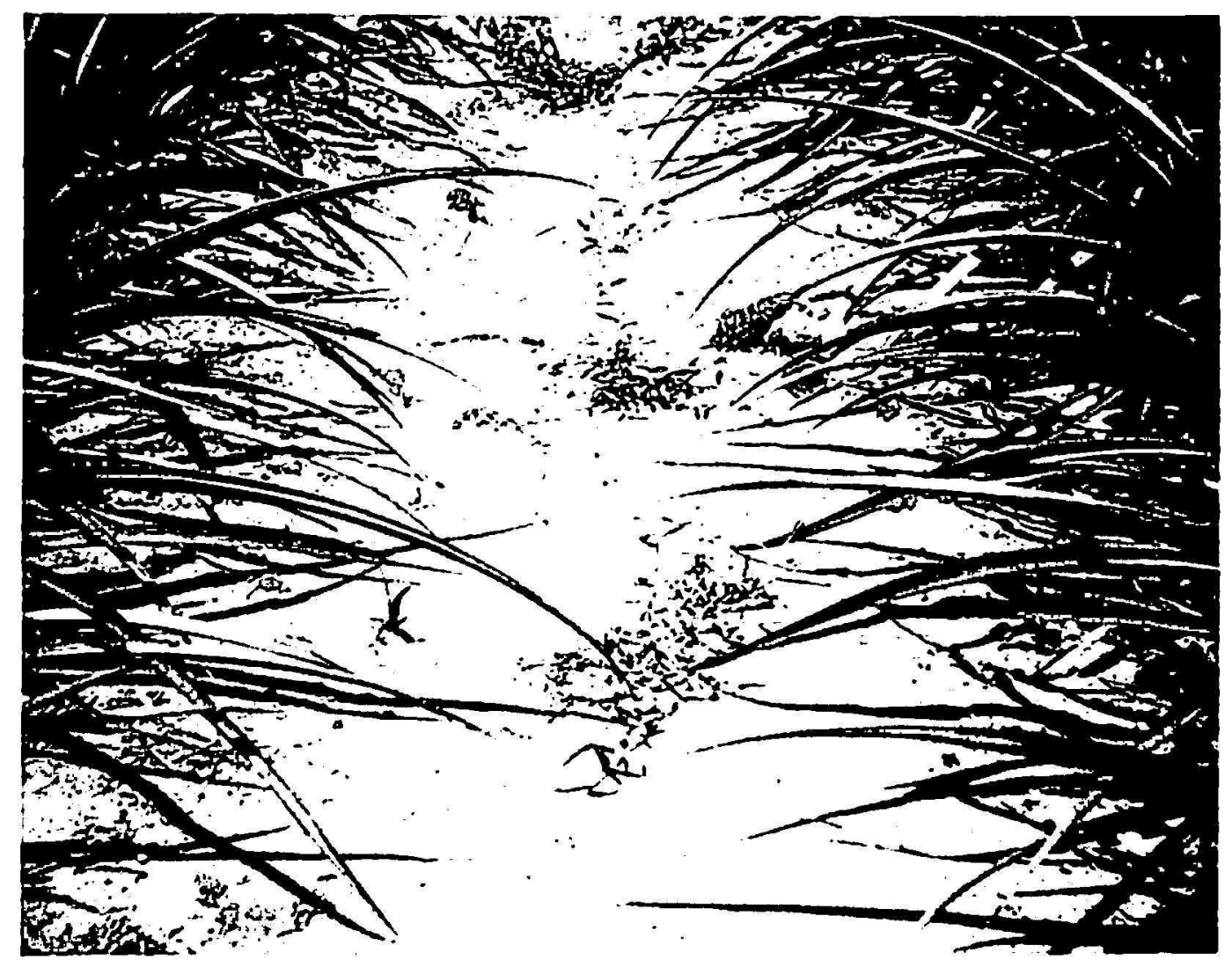

\section{$2 \mathrm{~A}$}

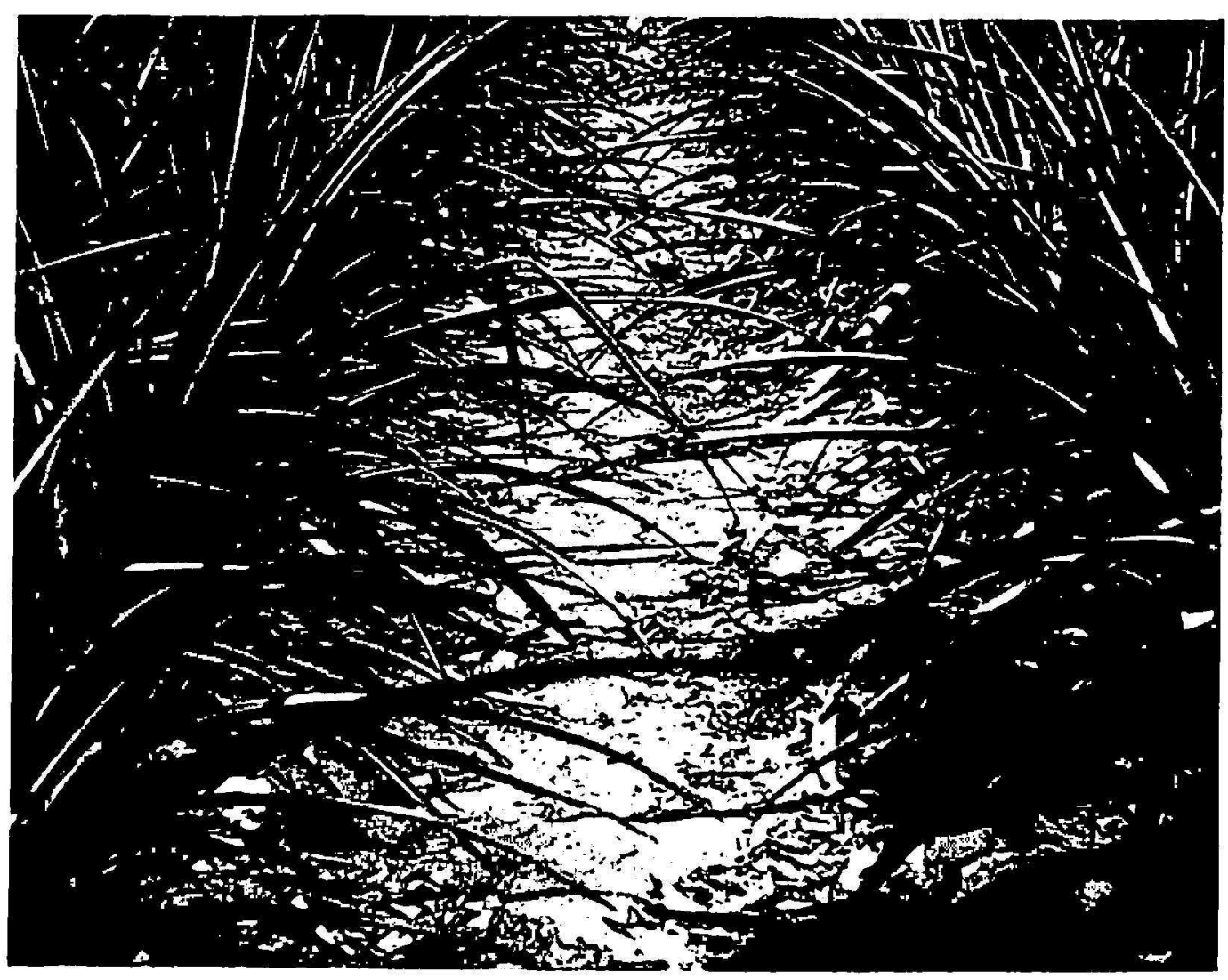

$2 \mathrm{~B}$

Fif. 2.-Cont rol of weeds by CMC applied to pineapple plots 6 mont hs after planting at rates of: $A, 2$ pounds per acre; $B, 4$ pounds per ace; $C, 6$ pounds per acre; $D$, ('ont rol. 

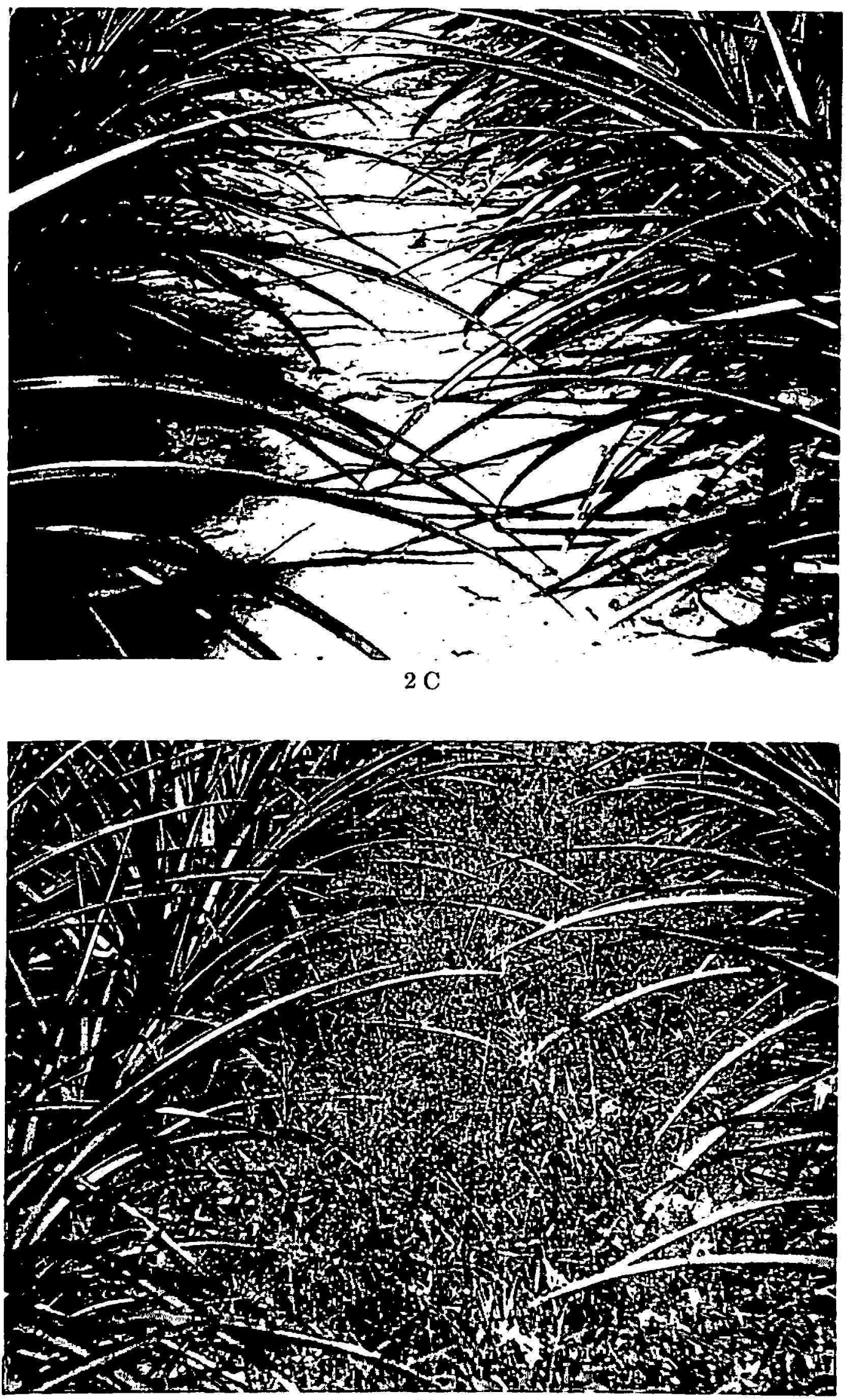
after planting, any of the CMU concentrations used would effectively control weeds in the field. However, by the end of this period there was a general tendency for the CMU-treated plots to produce fewer weeds as the concentration of the chemical was increased (tables 1 and 2). Apparently, the residual effects of CMU in this particular type of soil are related to the concentration in which it was applied. Thus, if a more lasting or prolonged control of weeds is desired, the higher concentrations are preferable.

\section{DISCUSSION}

The most abundant weed species in the control plots in both experiments were Bermuda grass (Cynodon dactylon L.) and pendejuelo grass (Digitaria sanguinalis Scop.). Pendejuelo grass was more prevalent than Bermuda grass. There were other grasses and broadleaf weeds in these plots, but very few. Bermuda grass was the only weed present in the treated plots.

As stated, the plants growing in the CMU-treated plots were examined periodically to determine whether this chemical had a detrimental effect at the concentrations and times of application used. But in no instance was any abnormal symptom noticed that could be attributed to the CMU. This was true of plants which received the chemical treatments 1 month or 6 months after planting. Not even plants which were treated for a second time with the CMU spray solution in the second experiment showed the slightest signs of injury. In other words, the pineapple plants in the CMUtreated plots, regardless of the concentrations or time of application used, looked as green and healthy as those growing in the control plots.

From the results obtained it can be concluded that CMU can be effectively used for the control of weeds in pineapple fields, at least in the northern pineapple region, for a prolonged period of time without injuring the plants.

\section{SUMMARY}

Costs of pineapple production in Puerto Rico are very high. Hand-hoeing of plantations is one of the items which contributes most to increase production expenses. Two experiments were conducted to determine the effectiveness and safeness of CMU for controlling weeds in pineapple fields economically. The results obtained were as follows:

1. Application of $\mathrm{CMU}$ at rates of 2,4 , and 6 pounds per acre significantly reduced the weed stand as compared to the control for a 3-month period in both experiments.

2. All CMU concentrations were equally effective in controlling weeds for about a 3-month period in both experiments.

3. No injury resulted from the application of $\mathrm{CMU}$ at the various con- 
centrations used 1 month or 6 months after planting the pineapples. Repetition of CMU treatments to plots in the second experiment was not detrimental to the plants.

\section{RESUMEN}

Los costos para producir la piña en Puerto Rico son sumamente altos. Una de las prácticas que más contribuye a mantener los gastos de producción altos es el desyerbo a mano de las plantaciones. En 1954 se llevaron a cabo dos experimentos con el fin de determinar la eficacia y seguridad del CMU para controlar económicamente los yerbajos en las plantaciones de piña. Los resultados fueron los siguientes:

1. Las aplicaciones de CMU a razón de $0,2,4$ y 6 libras redujeron significativamente el desarrollo de los yerbajos. Esto se comparó con los resultados en las parcelas testigos durante 3 meses en ambos experimentos.

2. Todas las concentraciones de CMU resultaron igualmente eficaces para controlar los yerbajos en ambos experimentos por un periodo de 3 meses.

3. No hubo efecto nocivo a las plantas de piña cuando se aplicó el CMU a distintas concentraciones, ni al mes, ni a los 6 meses después de la siembra. La repetición de los tratamientos de CMU a las parcelas del segundo experimento no fué perjudicial a las plantas de piña.

\section{LITERATURE CITED}

1. Craft, A. S., and Emmanueli, A., Some experiments with herbicides in pineapple, Bot. Gaz. 110 (2) 313-8, 1948.

2. Piñero, M., and Bayrón, H., Costos de producción de la piña en la zona norte de Puerto Rico (1948-1949), Bol. Est. Exp. Agr., Univ. P. R., Núm. 98, 1951. 